\title{
Assessment of low-cost, non-electrically powered chlorination devices for gravity-driven membrane water kiosks in eastern Uganda
}

\author{
Lukas Dössegger, Alan Tournefier, Laura Germann, \\ Nicola Gärtner, Timon Huonder, Cosmas Etenu, \\ Kennedy Wanyama, Henry Ouma, and Regula Meierhofer
}

\begin{abstract}
Recontamination during transport and storage is a common challenge of water supply in low-income settings, especially if water is collected manually. Chlorination is a strategy to reduce recontamination. We assessed seven low-cost, non-electrically powered chlorination devices in gravity-driven membrane filtration (GDM) kiosks in eastern Uganda: one floater, two in-line dosers, three end-line dosers (tap-attached), and one manual dispenser. The evaluation criteria were dosing consistency, user-friendliness, ease of maintenance, local supply chain, and cost. Achieving an adequate chlorine dosage $(\sim 2 \mathrm{mg} / \mathrm{L}$ at the tap and $\geq 0.2 \mathrm{mg} / \mathrm{L}$ after $24 \mathrm{~h}$ of storage in a container) was challenging. The T-chlorinator was the most promising option for GDM kiosks: it achieved correct dosage (CD, $1.5-2.5 \mathrm{mg} / \mathrm{L}$ ) with a probability of 90 per cent, was easy to use and maintain, economical, and can be made from locally available materials. The other in-line option, the chlorine-dosing bucket (40 per cent $C D$ ) still needs design improvements. The end-line options AkvoTur (67 per cent $C D$ ) and AquatabsFloß (57 per cent $C D$ ) are easy to install and operate at the tap, but can be easily damaged in the GDM set-up. The Venturi doser ( 52 per cent $C D$ ) did not perform satisfactorily with flow rates $>6 \mathrm{~L} / \mathrm{min}$. The chlorine dispenser (52 per cent $C D$ ) was robust and user-friendly, but can only be recommended if users comply with chlorinating the water themselves. Establishing a sustainable supply chain for chlorine products was challenging. Where solid chlorine tablets were locally rarely available, the costs of liquid chlorine options were high (27-162 per cent of the water price).
\end{abstract}

Keywords: point-of-collection chlorination, water treatment, recontamination, GDM water kiosk, low-income country

Lukas Dössegger (Lukas.doessegger@eawag.ch), Project Officer, Swiss Federal Institute of Aquatic

Science and Technology (Eawag); Alan Tournefier, MSc student, Eawag; Laura Germann, MSc student, Eawag; Nicola Gärtner, MSc student, Eawag; Timon Huonder, BSc student, Eawag;

Cosmas Etenu, Field Technician, Africa Water Solutions, Uganda; Kennedy Wanyama, Project Manager, Africa Water Solutions, Uganda; Henry Ouma (houma@africawatersolutions.org),

Project Leader, Africa Water Solutions, Uganda; Regula Meierhofer, Group Leader, Swiss Federal Institute of Aquatic Science and Technology (Eawag)

(c) The authors, 2021. This open access article is published by Practical Action Publishing and distributed under a Creative Commons Attribution CC BY 4.0 licence http://creativecommons.org/licenses/by/4.0/, www.practicalactionpublishing.com,

ISSN: 0262-8104/1756-3488 
SUSTAINABLE DEVELOPMENT GOAL (SDG) 6 calls for universal and equitable access to safe and affordable drinking water for all by 2030. Water kiosks contribute to SDG 6 by providing safe water at the community level in rural areas. Water is considered as safe if it meets the microbial guideline of the World Health Organization (WHO), which requires that $E$. coli must not be detected in any $100 \mathrm{ml}$ sample (WHO, 2017). Even though water might be safe at a communal water source, microbial water quality often deteriorates during transport and storage after collection (Wright et al., 2004; Harris et al., 2013; Opryszko et al., 2013; Meierhofer et al., 2019). Typically, $20 \mathrm{~L}$ jerry cans are used to transport and store drinking water in rural areas. Biofilms that grow inside these plastic containers and poor water, sanitation and hygiene (WASH) conditions can lead to recontamination (Jagals et al., 2003; Mellor et al., 2013; Opryszko et al., 2013). As a result, the water no longer meets the WHO microbial guideline at the point of consumption.

Chlorination is a water treatment strategy that provides residual disinfection, reducing recontamination risks during transport and storage. WHO recommends a concentration of $0.2-0.5 \mathrm{mg} / \mathrm{L}$ free residual chlorine (FRC) at the point of consumption (WHO, 2017). Consistent provision and consumption of treated water is important to maintain good health (Hunter, 2009; Brown and Clasen, 2012; Enger et al., 2013). However, users' compliance with chlorinating water at the household level often is inadequate and establishing the necessary level of compliance has been found to be difficult (McLaughlin et al., 2009; Levy et al., 2014). The installation of a chlorinator at the point of collection would circumvent the need to establish user compliance and can increase the proportion of chlorinated water available for consumption. Therefore, the objective of our study was to assess low-cost, non-electrically powered chlorinators at the point of collection.

\section{Methods}

\section{Gravity-driven membrane filtration water kiosks}

Together with local partners, five gravity-driven membrane (GDM) kiosks were constructed in low-income areas in eastern Uganda, with ultrafiltration membranes driven by gravity filter surface water pumped up with solar pumps from Lake Victoria (total organic carbon: $8 \mathrm{mg} / \mathrm{L}, \mathrm{pH}: 6$, turbidity: usually 10-25 NTU, peaks up to 150 NTU (Peter-Varbanets et al., 2017)). After filtration, the water at the tap meets the WHO microbial guideline value, but recontamination after transport and storage at the household level has been observed (Meierhofer et al., 2017). A scheme of the GDM kiosk is presented in Figure 1 .

\section{Assessed chlorinators}

Chlorinators can be electrically powered or non-electrically powered. Only non-electrically powered chlorinators were assessed in our study (Table 1): a manual chlorinator (chlorine dispenser), a diffusion chlorinator (floater), and waterpowered chlorinators, that is, in-line (T-chlorinator, chlorine-dosing bucket (CDB)) and end-line (AquatabsFloß, AkvoTur, Venturi). 


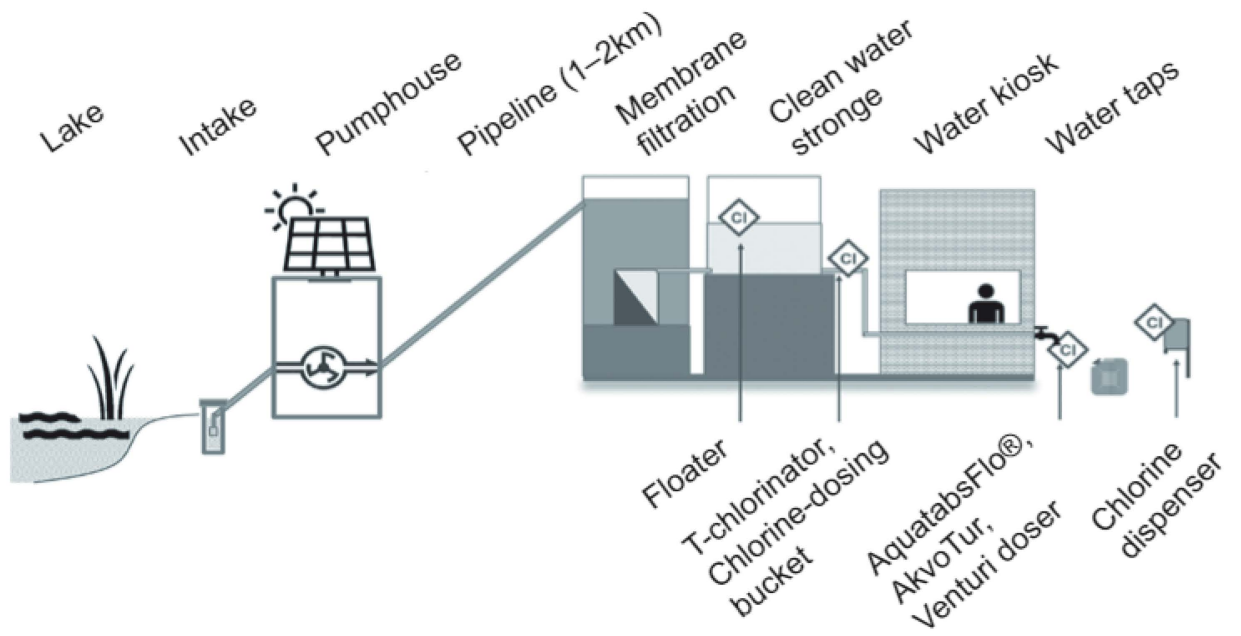

Figure 1 Scheme of GDM kiosk showing the different installation locations of assessed chlorinators

Table 1 Description of chlorinators assessed
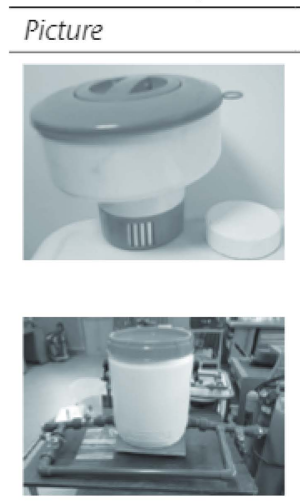
Device (installation)

Floater

(Clean water storage)

Multiple manufacturers

(e.g. Intex Recreation

Corp, California)

\section{Chlorine-dosing \\ bucket (CDB) (In-line)}

Design by Eawag
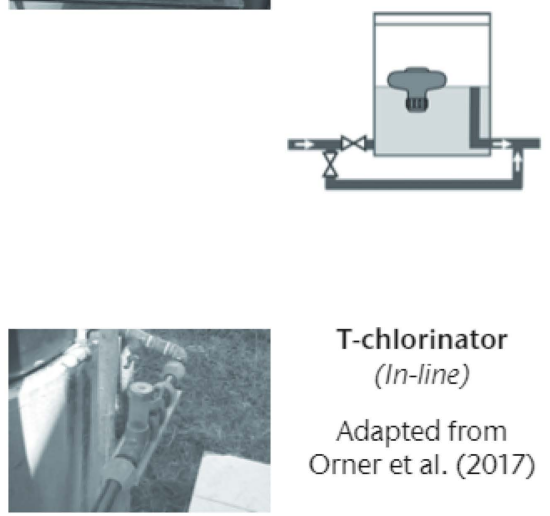

T-chlorinator (In-line) Orner et al. (2017)
Adapted from

Description

The floater floats in the clean water storage tank.

Slowly dissolving $90 \%$ trichloroisocyanuric acid

( $\mathrm{TCCA}$ ) tablets ( $\varnothing=3$ inches) are placed into the device and dissolve in the water. Opening or closing the slits at the bottom of the floater, as well as changing the number of tablets and the number of floaters, allow for adjusting the dosage.

The CDB is an air-tight closed bucket $(30 \mathrm{~L})$ with a bypass pipe that was installed in-line between the clean water tank and the kiosk's tap. A floater (see above), containing TCCA tablets ( $\left.\varnothing=3^{\prime \prime}\right)$, is placed inside the bucket. Valves at the inflow of the bucket and the bypass regulate the proportion of water passing through the CDB versus the bypass pipe and thereby regulate dosing. The higher the proportion of water passing through the bucket, the higher the chlorine concentration. To improve mixing behaviour, the inlet to the bucket is at the bottom and the outlet at the water surface. This is attained by an elbow with a $\sim 10 \mathrm{~cm}$ pipe facing upwards attached to the outlet.

The T-chlorinator consists of a cylinder with small holes that is placed into a T-fitting. It was installed in-line between the clean water tank and the kiosk's tap. The cylinder contains TCCA tablets $\left(\varnothing=1^{\prime \prime}\right)$, which are eroded by the flow of water. To adjust the dosage the number of tablets can be altered. Alternatively, different cylinders with different amounts and sizes of holes can be manufactured and can easily be exchanged. 
Table 1 Continued

\begin{tabular}{|c|c|c|}
\hline Picture & Device (installation) & Description \\
\hline Credit: SWAP Kenya & $\begin{array}{l}\text { Venturi doser } \\
\text { (Tap) } \\
\text { Mountain } \\
\text { Safety Research } \\
\text { (MSR, 2017) }\end{array}$ & $\begin{array}{l}\text { The Venturi doser uses the Venturi effect } \\
\text { for chlorine dosage. Water passes from a } \\
\text { pipe with a large diameter to a pipe with a } \\
\text { smaller diameter. This leads to an increase in } \\
\text { flow velocity, while the static fluid pressure } \\
\text { decreases. The pressure difference at the } \\
\text { constriction causes liquid chlorine to be 'sucked } \\
\text { in'. The Venturi doser needs to be operated end- } \\
\text { of-pipe and, therefore, was installed right before } \\
\text { the tap. A } 1.2 \% \text { NaOCl solution was used to } \\
\text { refill the device. A needle valve that restricts the } \\
\text { flow regulates the dosing. }\end{array}$ \\
\hline & $\begin{array}{l}\text { AquatabsFlo } \\
\text { (Tap) } \\
\text { (Manufactured } \\
\text { by Medentech } \\
\text { in Ireland) }\end{array}$ & $\begin{array}{l}\text { Water flowing through the AquatabsFlo }{ }^{\circ} \text { dissolves } \\
\text { sodium dichloroisocyanurate (NaDCC) tablets } \\
\text { placed inside the cartridge. The device was } \\
\text { installed after the tap with a bayonet catch for easy } \\
\text { removal. Tablets are not sold separately; thus, the } \\
\text { entire device is replaced if the chlorine is used up. } \\
\text { The concentration can be adjusted with a screw, } \\
\text { restricting the outflow, and thereby increasing the } \\
\text { contact time with the chlorine tablets. }\end{array}$ \\
\hline
\end{tabular}
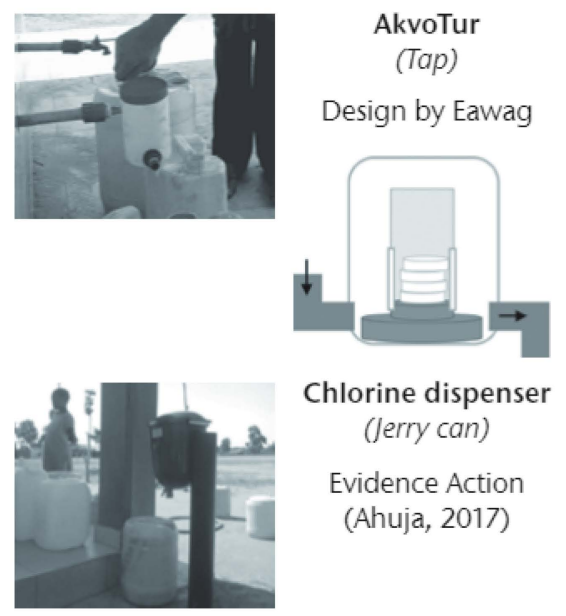

Chlorine dispenser (Jerry can)

Evidence Action (Ahuja, 2017)
Similar to the AquatabsFlo ${ }^{\circ}$, the device is installed after the tap. At the bottom of a container (ca. $1 \mathrm{~L}$, not airtight), a PVC plate is fixed, on which a PVC pipe can be placed. The pipe has two 2-mm slits. Water enters through one slit, erodes the TCCA tablets $\left(\varnothing=1^{\prime \prime}\right)$ inside and leaves through the opposite slit. To adjust the dosage, the PVC pipe can be turned. The more the slits face in the direction of the flow, the higher the concentration.

The chlorine dispenser is a container with a ball valve. It was the only 'non-passive' option evaluated and was located next to the water kiosk building. The case protects the chlorine from heat and, therefore, slows down decay. Customers place their $20 \mathrm{~L}$ jerry can filled with water below the dispenser and turn the ball valve to add chlorine to the jerry can. One turn releases $3 \mathrm{ml}$ of a $1.2 \% \mathrm{NaOCl}$.

A continuous and constant flow rate is optimal for water-powered and diffusion chlorinators (Skinner, 2001). GDM systems are therefore challenging to these kinds of chlorinators because the flow rate is variable (3-24 L/ $\mathrm{min})$ and the pressure is low $(2-30 \mathrm{kPa})$. The flow rate is determined by the water level in the storage tank and the height of the tank, and the pressure by the height difference between the level in the storage tank and the tap. 


\section{Adequate dosing}

Adequate dosing requires balancing several criteria. Branz (2017) advises to 1) meet the chlorine demand of the water; 2) maintain sufficient free residual chlorine (FRC) concentrations during transport and storage; and 3) avoid exceeding international maximum guideline values and user taste and odour objections. In the study area, the average chlorine demand was $1.8 \mathrm{mg} / \mathrm{L}$ over $24 \mathrm{~h}$ of storage in an uncleaned jerry can ( $\mathrm{n}=46$, standard deviation $(\mathrm{SD})=0.3 \mathrm{mg} / \mathrm{L}$ ). Wilhelm et al. (2018) and international guidelines (WHO, 2017; CDC, 2020) recommend $\geq 0.2 \mathrm{mg} / \mathrm{L}$ FRC after $24 \mathrm{~h}$ of transport and storage. WHO (2017) recommends a maximum of $5 \mathrm{mg} / \mathrm{L}$ FRC. Taste acceptability limits vary. In Bangladesh, the acceptability limit was found to be 'well below $2 \mathrm{mg} / \mathrm{L}$ ' (Crider et al., 2018), while in Zambia, water with $2 \mathrm{mg} / \mathrm{L}$ FRC was rated 'too strong and bitter', and in Ethiopia, $2 \mathrm{mg} / \mathrm{L}$ was 'noticeable' (Lantagne, 2008). In contrast, water tastings with households ( $\mathrm{n}=197, \mathrm{n}=$ sample number) in the study area revealed a high acceptance of water chlorinated with $2 \mathrm{mg} / \mathrm{L}$ FRC.

Balancing the three criteria, we targeted a FRC concentration of $2 \mathrm{mg} / \mathrm{L}$ at the tap. This is slightly higher than Wilhelm et al. (2018) recommend (1.88 $\mathrm{mg} / \mathrm{L}$ ) for improved or low turbidity sources for $24 \mathrm{~h}$ protection. The higher target concentration is due to the relatively high chlorine demand measured in the study area. Reasons for the high chlorine demand include biofilms attached to the storage container's walls and deposits (Jagals et al., 2003; Mellor et al., 2013; Opryszko et al., 2013), as well as the absence of a lid on most storage containers (Lantagne, 2008; Ali et al., 2015). Additionally, the high content of organic compounds (total organic carbon $=8 \mathrm{mg} / \mathrm{L}$ ) in the lake water could increase chlorine demand, similarly as observed in piped networks (Lu et al., 1999; Yee et al., 2006).

\section{Different chlorine products}

Solid and liquid chlorine products were used. The solid tablet form of chlorine is easier to handle and store as opposed to liquid chlorine, which has a shorter shelf life (Clasen and Edmondson, 2006). Solid chlorine was used in the form of slowly dissolving 90 per cent TCCA tablets and NaDCC tablets. Three-inch TCCA tablets (Henkel Polymer Ltd, US\$0.01/ $\mathrm{m}^{3}$ for $2 \mathrm{mg} / \mathrm{L}$; exchange rate: US\$1 = UGX 3,800) were available in Kampala, Uganda, at the time of the study. One-inch TCCA tablets were imported from Switzerland for the study. After the study, our local partner was able to purchase them in Nairobi $\left(\$ 0.02 / \mathrm{m}^{3}\right.$ for $\left.2 \mathrm{mg} / \mathrm{L}\right)$. NaDCC (Medentech, $\$ 0.22 / \mathrm{m}^{3}$ for $2 \mathrm{mg} / \mathrm{L}$ ) tablets are available in Uganda (direct communication by Medentech). Liquid chlorine was purchased at the local market as 1.2 per cent sodium hypochlorite solution $\left(\mathrm{NaOCl}, \$ 0.82-0.96 / \mathrm{m}^{3}\right.$ for $2 \mathrm{mg} / \mathrm{L}$ ) or self-produced as $\mathrm{NaOCl}$ solution (0.5-0.6 per cent), using a Mini-WATA ${ }^{\mathrm{TM}}$ electrochlorinator (Antenna Foundation, \$280). For liquid chlorine, the WATA system is economically attractive $\left(\sim \$ 0.15-0.59 / \mathrm{m}^{3}\right.$ for $2 \mathrm{mg} / \mathrm{L}$, including salt cost and device cost; lifespan of device: $1-5$ years; water production: $600-1,200 \mathrm{~m}^{3} /$ year) and circumvents the need for a chlorine supply chain. Nevertheless, the local kiosk operators expressed difficulties in handling and operating the device. 


\section{Evaluation criteria}

For each criterion, we developed a rating system and 'good', 'moderate', and 'poor' were the possible ratings.

Dosing consistency. Dosing consistency was defined as the probability of the device achieving a 'correct dosage' (CD) of 1.5-2.5 mg/L FRC at the kiosk's tap, balancing the minimum requirements of $\geq 0.2 \mathrm{mg} / \mathrm{L}$ after $24 \mathrm{~h}$ of storage and taste acceptability level $(\sim 2 \mathrm{mg} / \mathrm{L})$. The following ratings were applied: Good $\geq 90$ per cent, moderate $\geq 50$ per cent, and poor $<50$ per cent.

User-friendliness. If the operators reported that the device was easy to handle and did not express any complaints regarding its basic use (refilling chlorine products or adjusting chlorine dosage), the device received a good rating. If they reported difficulties or expressed a complaint regarding basic use (e.g. not easily accessible or the burden was beyond basic use), the rating attributed was moderate. If they were unable to use the device, the rating attributed was poor.

Ease of maintenance. If the device did not need to be repaired during the tests in the field, the rating attributed was good. If minor repairs had to be done that could be solved by the operator, the rating was moderate. If repairs could not be done by the operator or if any of the devices ceased to function, the rating attributed was poor.

Local supply chain. The following rating was applied regarding the local availability of the device and its spare parts: availability on the local market (LM) of Busia in eastern Uganda or in the neighbouring local market across the Kenyan border (rating $=$ good), in the country's capital Kampala (= moderate) or it needs to be imported (= poor). Local availability was evaluated separately for chlorine products and hardware, including spare parts.

Cost. Calculations include the cost of the chlorine to achieve $2 \mathrm{mg} / \mathrm{L}$ FRC and the cost of the device, but no labour costs. We considered different device lifespans (1-5 years) and capacities (600-1,200 $\mathrm{m}^{3} /$ year). The current water price is UGX 50/jerry can $\left(\$ 0.013=\$ 0.66 / \mathrm{m}^{3}\right)$. Assuming $900 \mathrm{~m}^{3}$ sold per year, a revenue of $\$ 592$ would be generated. After deducting salary costs and maintenance expenses, 16 per cent of the yearly income (\$93) would remain as profit. Under these assumptions, the cost of chlorinating the water cannot exceed $\$ 0.1 / \mathrm{m}^{3}$ (rating = good). A rise in the water price to UGX $100 /$ jerry can $(=\$ 1.32)$, as is common in other parts of Uganda, would enable a price of $\$ 0.59 / \mathrm{m}^{3}$ for chlorination (= moderate). For higher chlorination costs, the rating attributed was poor.

\section{Data collection and analysis}

The chlorinators were consecutively installed as shown in Figure 1 and dosing was adjusted to $\sim 2 \mathrm{mg} / \mathrm{L}$. Four of the seven devices were extensively tested (CDB, T-chlorinator, Venturi, and AkvoTur). FRC concentrations were measured at least once per week over 1.5-2 months. On every data collection day, a sample was taken every 5-15 min over 2-6 hours to capture the fluctuation of flow rates. 
The remaining three devices were tested less extensively. For the floater and the chlorine dispenser, samples were taken over 3-5 days during one week, and for the AquatabsFlo ${ }^{\circledR}$, samples were taken over $0.5 \mathrm{~h}$ on two days. Flow rates were not recorded.

FRC was measured using a LaMotte DC1500-CL colorimeter and diethylphenylenediamine (DPD) tablets (LaMotte DPD1 TesTabs). Samples were taken at the tap of the GDM kiosks. The tap was opened, flushed for 10 seconds and a $10 \mathrm{ml}$ vial was rinsed three times. Then, the sample was taken and immediately analysed. Samples from the chlorine dispenser were taken from the jerry can after the water was chlorinated and the jerry can was shaken.

To gain insight on user-friendliness, ease of maintenance, local supply chain, and costs, we 1) conducted qualitative interviews with the kiosk operators and staff from our local partner organization; 2) searched local markets for devices and consumables; and 3) evaluated observations of the research staff involved in the fieldwork. In addition, the operators were trained by our local partner organization to use the devices. The operators and NGO staff were informed about the goal, purpose, and methodology of the study and asked for informed consent. The study protocol was reviewed and approved by the Ethics Committee of Makerere University on 18 July 2018, the Uganda National Council for Science and Technology, and the Ethical Committee of Eawag, the Swiss Federal Institute of Aquatic Science and Technology on 6 June 2018.

Data was analysed using Excel and R-Studio. To test for normal distribution, histograms and one-sample Kolmogorov-Smirnov tests (two-sided) were used. FRC measurements were normally distributed $(p>0.05)$. The Pearson correlation coefficient (two-tailed) and linear regression models were used to explore the correlation between FRC concentrations and flow rate.

\section{Results and discussion}

\section{Floater}

The floater is commonly used to chlorinate swimming pools. In a technical manual, Luff (2001) mentioned the use of this device to chlorinate drinking water. However, the authors are not aware of any study that has assessed the floater's performance in chlorinating drinking water.

Our data indicates that the floater did not achieve consistent dosage $(\overline{\mathrm{x}}=1.5 \mathrm{mg} / \mathrm{L}$ $(\overline{\mathrm{x}}=$ mean $), \mathrm{SD}=0.9 \mathrm{mg} / \mathrm{L}, \mathrm{min}=0.1 \mathrm{mg} / \mathrm{L}, \max =3.1 \mathrm{mg} / \mathrm{L}, \mathrm{CD}=37$ per cent, $\mathrm{n}=15$ ). During the analysis, the storage tank was constantly less than a quarter full. As the floater is placed in the storage tank, it is difficult to refill the tablets and to adjust the dosing. A positive factor, however, is that the floater is robust, available in Kampala and can be operated at low cost $\left(\sim \$ 0.02 / \mathrm{m}^{3}\right)$. Yet, in the context of the GDM set-up, it is problematic to chlorinate the water from the inside of the storage tank as chlorinated water could flow back from the storage tank to the membrane tank and damage the membranes. Further studies are needed concerning the use of this device. Intermittent or variable flow also influences the dosing reliability because the contact time with the water varies. 


\section{Chlorine-dosing bucket (CDB)}

The CDB was designed after observing challenges with the floater in the GDM set-up. The floater was integrated into an in-line device developed at Eawag. No similar use of a floater is known to the authors.

The CDB did not achieve consistent dosage $(\overline{\mathrm{x}}=1.7, \mathrm{SD}=0.9 \mathrm{mg} / \mathrm{L}, \mathrm{min}=0.3 \mathrm{mg} / \mathrm{L}$, $\max =3.5 \mathrm{mg} / \mathrm{L}, \mathrm{CD}=40$ per cent, $n=56$, flow rate $=2.7-7.5 \mathrm{~L} / \mathrm{min}$ ). In a simple linear regression model, the flow rate and FRC concentrations were significantly correlated $(R=-0.75, p=0.003)$. To reduce the flow dependency, the proportion of water passing the bucket could be reduced or the size of the bucket increased. This is predicted by the steady state solution of the mass balance equation (Equation 1 ) and should be further researched. Some positive aspects are that the CDB is user-friendly, robust, can be made from low-cost locally available materials, and operated at low $\cos t\left(\leq \$ 0.1 / \mathrm{m}^{3}\right)$.

$$
C_{\text {out }}=\frac{k_{\text {dissolution }} \times V}{Q_{1}+k_{\text {decay }} \times V} \times \frac{Q_{1}}{Q_{\text {tot }}}
$$

where: $C_{\text {out }}=$ FRC concentration after $\mathrm{CDB}[\mathrm{mg} / \mathrm{L}]$

$V=$ volume of the bucket of the CDB $[\mathrm{L}]$

$Q_{1}=$ flow passing bucket $[\mathrm{L} / \mathrm{min}]$

$Q_{\text {tot }}=$ total flow passing bypass and bucket [L/min]

$k_{\text {decay }}=$ chlorine decay rate $[\mathrm{L} / \mathrm{min}]$

$k_{\text {dissolution }}=$ chlorine dissolution rate $\left[\mathrm{mg} / \mathrm{L}^{*} \mathrm{~min}\right]$

\section{T-chlorinator}

The T-chlorinator assessed in this study is an adaption of the model looked at by Orner et al. (2017). They used the chlorinator in a gravity-fed piped distribution system. Compared to our study, the flow rate was substantially higher $(60 \mathrm{~L} / \mathrm{min})$ and the target concentration substantially lower $(0.27 \mathrm{mg} / \mathrm{L})$.

In our assessment, the T-chlorinator achieved the best dosing consistency of all devices $(\overline{\mathrm{x}}=2.0 \mathrm{mg} / \mathrm{L}, \mathrm{SD}=0.3 \mathrm{mg} / \mathrm{L}, \min =1.1 \mathrm{mg} / \mathrm{L}, \max =3.0 \mathrm{mg} / \mathrm{L}$, $\mathrm{CD}=90$ per cent, $n=64$, flow rate $=3-8 \mathrm{~L} / \mathrm{min})$. No significant correlation between the flow rate and FRC concentration was found ( $R=-0.23$, $p=0.070)$, which is consistent with Orner et al. (2017). The device is userfriendly and robust. The materials to build the device are inexpensive $(\sim \$ 15)$ and available in Uganda, except for the required 1-inch chlorine tablets that need to be imported from Nairobi, Kenya. The operating costs $\left(\leq \$ 0.05 / \mathrm{m}^{3}\right)$ are relatively low.

\section{Venturi doser}

The Venturi doser was developed by MSR, PATH, and Stanford University. The device has been extensively tested in the laboratory for flow rates of $10-40 \mathrm{~L} / \mathrm{min}$ (SWAP, 2017). In field experiments, the device dosed consistently 1-1.5 $\mathrm{mg} / \mathrm{L}$ (target concentration: $1 \mathrm{mg} / \mathrm{L}$, flow rate $20-40 \mathrm{~L} / \mathrm{min}$, (SWAP, 2017)). 
In our assessment, the dosing was less consistent for a flow rate of $6-20 \mathrm{~L} / \mathrm{min}$ $(\overline{\mathrm{x}}=2.1 \mathrm{mg} / \mathrm{l}, \mathrm{SD}=0.7 \mathrm{mg} / \mathrm{L}, \mathrm{min}=0.2 \mathrm{mg} / \mathrm{L}, \max =3.3 \mathrm{mg} / \mathrm{L}, \mathrm{CD}=52$ per cent, $n=58$ ). For flow rates below $6 \mathrm{~L} / \mathrm{min}$, which sometimes occur at GDM kiosks, the WHO guideline value of $5 \mathrm{mg} / \mathrm{L}(\mathrm{WHO}, 2017)$ was exceeded. No significant correlation between the flow rate and FRC $(R=-0.3, p=0.121)$ was observed. The operators were able to handle the Venturi doser. Even though the device is made of fragile parts, they are all protected in a robust metal box. No repairs were required. The device is still a prototype, is not available locally, and is relatively expensive $(\$ 150)$. Liquid chlorine is available locally $\left(\sim \$ 0.82 / \mathrm{m}^{3}\right)$ or can be selfproduced $\left(\sim 0.17-0.59 / \mathrm{m}^{3}\right)$, but at relatively high costs.

\section{AquatabsFlo}

Pickering et al. (2019) assessed the AquatabsFlo $®$ to chlorinate water at the point of collection and reported an average FRC concentration of $0.37 \mathrm{mg} / \mathrm{L}(\mathrm{SD}=0.32$, target concentration: $0.2-0.5 \mathrm{mg} / \mathrm{L}, n=2,335$ ).

We found the dosing consistency to be moderate $(\overline{\mathrm{x}}=2.2 \mathrm{mg} / \mathrm{L}, \mathrm{SD}=0.6 \mathrm{mg} / \mathrm{L}$, $\min =1.7 \mathrm{mg} / \mathrm{L}, \max =3.6 \mathrm{mg} / \mathrm{L}, \mathrm{CD}=57$ per cent, $n=8$ ). However, the findings are based on only eight samples. Failure of the device to chlorinate (FRC $\leq 0.2 \mathrm{mg} / \mathrm{L}$ ) was observed four times prior to data collection, and two times during data collection. Removing, shaking, and reinstalling the device restored FRC concentrations to $\sim 2 \mathrm{mg} / \mathrm{L}$. The two failed measurements were not included in the analysis. Adjusting the dosage with the provided screw was difficult. Furthermore, the device had to be removed from the kiosk's tap when the kiosk closed at night to prevent vandalism and frequent removal can damage the plastic bayonet catch. In other set-ups, the cartridge can be permanently installed before the storage tank, where it is better protected (Pickering et al., 2019). The device, including chlorine tablets, is available in Kampala. When the tablets are used up, the whole device has to be replaced. This leads to an increase in costs $\left(\$ 0.22 / \mathrm{m}^{3}\right.$ for $2 \mathrm{mg} / \mathrm{L}$ ).

\section{AkvoTur}

The AkvoTur is similar to the AquatabsFlo ${ }^{\circledR}$, but with a better mechanism to adjust dosage and the option to refill chlorine tablets. It was designed at Eawag.

The dosing consistency of the AkvoTur was moderate $(\overline{\mathrm{x}}=2.1 \mathrm{mg} / \mathrm{L}, \mathrm{SD}=0.5 \mathrm{mg} / \mathrm{L}$, $\min =0.8 \mathrm{mg} / \mathrm{L}, \max =3.6 \mathrm{mg} / \mathrm{L}, \mathrm{CD}=67$ per cent, $n=78$, flow rate $=2.5-9 \mathrm{~L} / \mathrm{min}$ ). No significant correlation between the flow rate and the FRC concentration was observed $(R=0.09, p=0.436)$. The device cannot handle flow rates above $12 \mathrm{~L} / \mathrm{min}$, as this would cause overflow. The handling is similar to the AquatabsFlo $\AA$, but overdosing is possible if the cylinder containing the tablets is not positioned correctly. Like the AquatabsFlo ${ }^{\circledR}$, the AkvoTur had to be removed daily from the kiosk's tap to prevent vandalism. The plastic threading suffers from the daily removal; therefore, the design needs improvements. Materials to produce the AkvoTur are available locally at low cost $(\sim \$ 7)$. As for the T-chlorinator, the 1 -inch tablets need to be imported from Nairobi, Kenya. 


\section{Chlorine dispenser}

Over 27,000 chlorine dispensers have been installed in Kenya, Uganda, and Malawi (Ahuja, 2017). Yates et al. (2015) studied dispenser programmes in four emergency situations. The programmes always employed a local promoter for community training. Confirmed dispenser use (FRC $\geq 0.2 \mathrm{mg} / \mathrm{L}$ in stored household water) ranged from 5 to 87 per cent.

Table 2 Evaluation matrix (white $=$ good, grey $=$ moderate, black = poor)

\begin{tabular}{|c|c|c|c|c|c|c|c|}
\hline \multirow{2}{*}{$\begin{array}{c}\text { Device } \\
\text { (price, US\$) }\end{array}$} & \multirow{2}{*}{$\begin{array}{c}\text { Dosing } \\
\text { consistency? }\end{array}$} & \multirow{2}{*}{$\begin{array}{c}\text { User- } \\
\text { friendliness }\end{array}$} & \multirow{2}{*}{$\begin{array}{c}\text { Ease of } \\
\text { maintenance }\end{array}$} & \multicolumn{2}{|c|}{ Supply chain } & \multirow{2}{*}{\multicolumn{2}{|c|}{$\begin{array}{c}\operatorname{Cost}^{2} \\
\left(U S \$ / m^{3}\right)\end{array}$}} \\
\hline & & & & Chlorine & $\begin{array}{c}\text { Device and } \\
\text { parts }\end{array}$ & & \\
\hline Floater $(\sim \$ 7)$ & $\begin{array}{c}37 \% \\
{[1.5 \pm 0.9} \\
\mathrm{mg} / \mathrm{L}]\end{array}$ & $\begin{array}{l}\text { Difficult to } \\
\text { refill }\end{array}$ & $\begin{array}{c}\text { Robust, few } \\
\text { wearing parts }\end{array}$ & $\begin{array}{l}3^{\prime \prime} \text { TCCA, } \\
\text { Kampala }\end{array}$ & Kampala & $0.01-$ & 0.02 \\
\hline $\mathrm{CDB}(\sim \$ 50)$ & $\begin{array}{c}40 \% \\
{[1.7 \pm 0.9} \\
\mathrm{mg} / \mathrm{L}] \\
\text { Flow } \\
\text { dependent }\end{array}$ & Easy to use & $\begin{array}{l}\text { Robust, few } \\
\text { wearing parts }\end{array}$ & $\begin{array}{l}3^{\prime \prime} \text { TCCA, } \\
\text { Kampala }\end{array}$ & $\begin{array}{l}\text { Device } \\
\text { can be } \\
\text { made } \\
\text { locally }\end{array}$ & 0.02 & 0.10 \\
\hline $\begin{array}{c}\text { T-chlorinator } \\
(\sim \$ 15)\end{array}$ & $\begin{array}{c}90 \% \\
{[2.0 \pm 0.3} \\
\mathrm{mg} / \mathrm{L}]\end{array}$ & Easy to use & $\begin{array}{c}\text { Robust, few } \\
\text { wearing parts }\end{array}$ & $\begin{array}{l}\text { 1" TCCA, } \\
\text { Nairobi, } \\
\text { Kenya }\end{array}$ & $\begin{array}{l}\text { Device } \\
\text { can be } \\
\text { made } \\
\text { locally }\end{array}$ & 0.02 & 0.05 \\
\hline $\begin{array}{l}\text { Venturi doser } \\
\qquad\left(\sim \$ 150^{3}\right)\end{array}$ & $\begin{array}{c}52 \% \\
{[2.1 \pm 0.7} \\
\mathrm{mg} / \mathrm{L}] \\
\text { Above } 6 \mathrm{~L} / \\
\text { min }\end{array}$ & Easy to use & $\begin{array}{l}\text { Fragile, } \\
\text { but well } \\
\text { protected } \\
\text { parts }\end{array}$ & $\begin{array}{c}\mathrm{NaOCl} \\
\mathrm{LM}^{5} \text { or } \mathrm{SP}^{6}\end{array}$ & $\begin{array}{l}\text { Prototypes } \\
\text { from USA }\end{array}$ & $\begin{array}{c}0.85- \\
1.07 \\
\left(\mathrm{LM}^{5}\right)\end{array}$ & $\begin{array}{l}0.18- \\
0.82 \\
\left(\mathrm{SP}^{6}\right)\end{array}$ \\
\hline $\begin{array}{l}\text { AquatabsFlo } \\
\qquad\left(\sim 20^{4}\right)\end{array}$ & $\begin{array}{c}57 \% \\
{[2.2 \pm 0.6} \\
\mathrm{mg} / \mathrm{L}] \\
\text { chlorination } \\
\text { failure } \\
\text { occurred }\end{array}$ & $\begin{array}{c}\text { Daily } \\
\text { installation } \\
\text { needed }\end{array}$ & $\begin{array}{l}\text { Not durable, } \\
\text { device needs } \\
\text { replacement } \\
\text { with tablets }\end{array}$ & $\begin{array}{l}\text { NaDCC, } \\
\text { Kampala }\end{array}$ & Kampala & 0.2 & \\
\hline AkvoTur ( $\$ 7)$ & $\begin{array}{c}67 \% \\
{[2.1 \pm 0.5} \\
\mathrm{mg} / \mathrm{L}] \\
\text { Up to } 12 \mathrm{~L} / \\
\min \end{array}$ & $\begin{array}{c}\text { Daily } \\
\text { installation } \\
\text { needed; } \\
\text { overdose } \\
\text { possible }\end{array}$ & $\begin{array}{c}\text { Not durable, } \\
\text { wearable } \\
\text { parts }\end{array}$ & $\begin{array}{l}\text { 1" TCCA, } \\
\text { Nairobi, } \\
\text { Kenya }\end{array}$ & $\begin{array}{l}\text { Device } \\
\text { can be } \\
\text { made } \\
\text { locally }\end{array}$ & 0.02 & 0.03 \\
\hline $\begin{array}{l}\text { Dispenser } \\
(\sim \$ 20)\end{array}$ & $\begin{array}{c}52 \% \\
{[1.9 \pm 0.7} \\
\mathrm{mg} / \mathrm{L}] \\
6 \mathrm{ml} \mathrm{NaOCl} \\
\text { per jerry can }\end{array}$ & Easy to use & $\begin{array}{l}\text { Robust, few } \\
\text { fragile parts }\end{array}$ & $\begin{array}{c}\mathrm{NaOCl}, \\
\mathrm{LM}^{5} \text { or SP }\end{array}$ & Kampala & $\begin{array}{c}0.96- \\
0.99 \\
\left(\mathrm{LM}^{5}\right)\end{array}$ & $\begin{array}{l}0.18- \\
0.63 \\
\left(\mathrm{SP}^{6}\right)\end{array}$ \\
\hline
\end{tabular}

Note: ${ }^{1}$ Probability to achieve $1.5-2.5 \mathrm{mg} / \mathrm{L}$ [mean $\left.\mathrm{FRC} \pm \mathrm{SD}\right] ;{ }^{2}$ chlorination to $2 \mathrm{mg} / \mathrm{L}$ for a device lifespan of $1-5$ years and production of $600-1,200 \mathrm{~m}^{3} / \mathrm{year} ;{ }^{3}$ estimated product price if mass produced according to MSR; ${ }^{4}$ including chlorine tablets; ${ }^{5}$ local market; ${ }^{6}$ self-produced 
The dispenser releases $3 \mathrm{ml}$ of $\mathrm{NaOCl}$ per turn of the ball valve. In our assessment, one turn provided a mean $0.9 \mathrm{mg} / \mathrm{L}$ in a $20 \mathrm{~L}$ jerry can $(\mathrm{SD}=0.2 \mathrm{mg} / \mathrm{L}, \mathrm{min}=$ $0.5 \mathrm{mg} / \mathrm{L}, \max =1.3 \mathrm{mg} / \mathrm{L}, n=27)$, and two turns $1.9 \mathrm{mg} / \mathrm{L}(\mathrm{SD}=0.7 \mathrm{mg} / \mathrm{L}, \mathrm{min}$ $0.6 \mathrm{mg} / \mathrm{L}, \max =3.9 \mathrm{mg} / \mathrm{L}, \mathrm{CD}=52$ per cent, $n=17$ ). The device is easy to use, robust, and available in Kampala at $\sim 20$. The liquid chlorine is available locally at $\sim \$ 0.96 / \mathrm{m}^{3}$ or can be self-produced $\left(\sim 0.17-0.59 / \mathrm{m}^{3}\right)$. As users have to chlorinate the water themselves, it is likely that the water would not always be chlorinated before consumption. This was confirmed by observations of the operator, as well as by Yates et al. (2015). The dependence upon user compliance is a significant disadvantage of the chlorine dispenser. Table 2 summarizes the assessment of the different chlorination devices.

\section{Limitations}

Due to how the data collection in the field was done, the number of samples taken for FRC measurements of the different devices vary. While the sample sizes for AquatabsFlo ${ }^{\circledR}(n=8)$, the chlorine dispenser $(n=27)$, and the floater ( $n=15)$ are limited, they are much larger for the other devices $(n=56-78)$. As the sample size increases, the sampling distribution clusters more tightly around the mean and, consequently, the standard deviations shrink. Therefore, our results might overestimate the standard deviation of the devices with small sample sizes.

\section{Conclusion and recommendations}

Seven low-cost, non-electrically powered chlorinators were assessed at GDM water kiosks in eastern Uganda. Dosing consistency was challenging. Only the T-chlorinator had a probability $\geq 90$ per cent to achieve the target concentration of $1.5-2.5 \mathrm{mg} / \mathrm{L}$ FRC at the tap. The probabilities of reaching the target concentration of the AkvoTur, the Venturi doser, the AquatabsFlo ${ }^{\circledR}$, and the chlorine dispenser were 52-67 per cent, and of the floater and the $\mathrm{CDB}<40$ per cent.

All the devices assessed were user-friendly and easy to maintain, except for the floater, which is difficult to refill, and the tap-attached options AkvoTur and AquatabsFlo ${ }^{\circledR}$, which need to be removed daily in the GDM set-up to prevent vandalism. Because of the daily removal of these devices, the risk of damage during handling is increased. In other set-ups, these devices can be installed before the clean water tank, and are, therefore, better protected (Pickering et al., 2019). The Venturi doser is also attached to the tap, but it is robust and can be permanently installed. The findings of the Venturi doser, however, indicate inconsistent dosing when flow rates drop below $6 \mathrm{~L} / \mathrm{min}$.

All the devices or parts needed to construct them, as well as chlorine products, are available in Uganda or the border town in Kenya that is $1 \mathrm{~km}$ away, except for the Venturi doser and the 1-inch TCCA chlorine tablets. In the calculated scenarios (600-1,200 $\mathrm{m}^{3}$ chlorinated water/year over $1-5$ years), the chlorination costs of the tablet-based options were $\leq \$ 0.1 / \mathrm{m}^{3}$ and could be covered by the revenues of 
the kiosk. The only exception was the AquatabsFlo@ $\left(\$ 0.22 / \mathrm{m}^{3}\right)$. The costs of the liquid chlorine-based options were between $\$ 0.18$ and $\$ 1.07 / \mathrm{m}^{3}$ and could not be covered by the revenues of the kiosk given the current water price $\left(\$ 0.66 / \mathrm{m}^{3}\right)$. Adding the cost for liquid chlorination to the water price, therefore, would have a significant impact on the business model.

Overall, the T-chlorinator performed best in our assessment for the GDM kiosks, which are characterized by low pressure (2-30 kPa), a variable and low flow rate (3-24 L/min), and no possibility to install the tap-attached options in a safe place. However, the required 1-inch TCCA tablets need to be imported from Nairobi, Kenya.

The chlorine dispenser is the only option where users have to chlorinate the water manually themselves. Establishing a consistent practice to do so on the part of users has been found to be difficult (Yates et al., 2015), but is critical for health improvements (Hunter, 2009; Brown and Clasen, 2012; Enger et al., 2013). Therefore, the chlorine dispenser can only be recommended if user compliance were high.

Even though the GDM kiosks in this study have a specific design, general recommendations can be drawn from our experience.

1. If the chlorine demand of the water is high ( $>1.3 \mathrm{mg} / \mathrm{L}$ over $24 \mathrm{~h}$ ), it may be difficult to find a chlorinator that consistently ( $\geq 90$ per cent) guarantees $\geq 0.2 \mathrm{mg} / \mathrm{L}$ FRC after $24 \mathrm{~h}$ of storage and at the same time does not interfere with taste acceptability $(\sim 2 \mathrm{mg} / \mathrm{L}$ ). In this case, measures to reduce the chlorine demand are recommended; for example, safe storage containers (Roberts et al., 2001; Reed et al., 2011; Mellor et al., 2013; Gärtner et al., 2020) or periodically cleaning and disinfecting the containers (Steele et al., 2008; Meierhofer et al., 2019; Gärtner et al., 2020).

2. The installation of in- or end-line chlorination options offers a potential solution to circumvent the challenge of establishing consistent and correct manual chlorine dosing by the user. However, low-pressure systems and variable flow rates pose challenges to the dosing consistency of many in- and end-line chlorinators. Further developing these kinds of devices to improve their performance is required.

3. The establishment of a reliable and affordable supply chain for the chlorine products suitable for drinking water treatment may be challenging. Yet, it is a key factor for the sustainable operation of chlorination devices.

\section{References}

Ahuja, A. (2017) 'Dispensers for safe water: an updated review of the evidence', Evidence Action [online] <https://www.evidenceaction.org/dispensers-for-safe-water-an-updated-reviewof-the-evidence/> [accessed 19 May 2020].

Ali, S.I., Ali, S.S. and Fesselet, J.-F. (2015) 'Effectiveness of emergency water treatment practices in refugee camps in South Sudan', Bulletin of the World Health Organization 93: 550-8 <https://doi.org/10.2471/BLT.14.147645>. 
Branz, A. (2017) 'Chlorination of drinking water in emergencies: a review of knowledge to develop recommendations for implementation and research needed', Waterlines 36(1): 4-39 $<$ http://dx.doi.org/10.3362/1756-3488.2017.002>.

Brown, J. and Clasen, T. (2012) 'High adherence is necessary to realize health gains from water quality interventions', PloS one 7(5): e36735 <http://doi.org/10.1371/journal.pone. $0036735>$.

Centers for Disease Control and Prevention (CDC) (2020) 'Free chlorine testing', CDC [online] <https://www.cdc.gov/safewater/chlorine-residual-testing.html > [accessed 25 November 2020].

Clasen, T. and Edmondson, P. (2006) 'Sodium dichloroisocyanurate (NaDCC) tablets as an alternative to sodium hypochlorite for the routine treatment of drinking water at the household level', International Journal of Hygiene and Environmental Health 209(2): 173-81 <https://doi. org/10.1016/j.ijheh.2005.11.004>.

Crider, Y., Sultana, S., Unicomb, L., Davis, J., Luby, S.P. and Pickering, A.J. (2018) 'Can you taste it? Taste detection and acceptability thresholds for chlorine residual in drinking water in Dhaka, Bangladesh', Science of the Total Environment 613: 840-6 <http://doi.org/10.1016/ j.scitotenv.2017.09.135>.

Enger, K.S., Nelson, K.L., Rose, J.B. and Eisenberg, J.N. (2013) 'The joint effects of efficacy and compliance: a study of household water treatment effectiveness against childhood diarrhea', Water Research 47(3): 1181-90<https://doi.org/10.1016/j.watres.2012.11.034>.

Gärtner, N., Germann, L., Wanyama, K., Ouma, H. and Meierhofer, R. (2020) 'Keeping water from kiosks clean: strategies for reducing recontamination during transport and storage in eastern Uganda', Water Research X: 100079 <https://doi.org/10.1016/j.wroa.2020.100079>.

Harris, A.R., Davis, J. and Boehm, A.B. (2013) 'Mechanisms of post-supply contamination of drinking water in Bagamoyo, Tanzania', Journal of Water and Health 11(3): 543-54 <http://doi. org/10.2166/wh.2013.023>.

Hunter, P.R. (2009) 'Household water treatment in developing countries: comparing different intervention types using meta-regression', Environmental Science and Technology 43(23): 8991-7 $<$ https://doi.org/10.1021/es9028217>.

Jagals, P., Jagals, C. and Bokako, T. (2003) 'The effect of container-biofilm on the microbiological quality of water used from plastic household containers', Journal of Water and Health 1(3): 101-8 <http://doi.org/10.2166/wh.2003.0012>.

Lantagne, D.S. (2008) 'Sodium hypochlorite dosage for household and emergency water treatment', Journal of the American Water Works Association 100(8): 106-19 <https://doi. org/10.1002/j.1551-8833.2008.tb09704.x>.

Levy, K., Anderson, L., Robb, K.A., Cevallos, W., Trueba, G. and Eisenberg, J.N. (2014) 'Household effectiveness vs. laboratory efficacy of point-of-use chlorination', Water Research 54: 69-77 〈http://doi.org/10.1016/j.watres.2014.01.037〉.

Lu, W., Kiéné, L. and Lévi, Y. (1999) 'Chlorine demand of biofilms in water distribution systems', Water Research 33(3): 827-35 <http://doi.org/10.1016/S0043-1354(98)00229-2>.

Luff, R. (2001) Instruction Manual for Coagulation and Disinfection Equipment: Covering Upflow Clarifier, Chlorine and Aluminium Sulphate Dosing Options, Oxford, UK: Oxfam.

McLaughlin, L.A., Levy, K., Beck, N.K., Shin, G.-A., Meschke, J.S. and Eisenberg, J.N. (2009) 'An observational study on the effectiveness of point-of-use chlorination', Journal of Environmental Health 71(8): 48. 
Meierhofer, R., Rubli, P., Dreyer, K., Ouma, H., Wanyama, K. and Peter-Varbanets, M. (2017) 'Membrane filtration reduces recontamination risk in chlorinated household water containers', paper presented at the 40th WEDC International Conference, Loughborough, UK [online] <https:// hdl.handle.net/2134/31506> [accessed 12 March 2021].

Meierhofer, R., Wietlisbach, B. and Matiko, C. (2019) 'Influence of container cleanliness, container disinfection with chlorine, and container handling on recontamination of water collected from a water kiosk in a Kenyan slum', Journal of Water and Health 17(2): 308-17 $<$ https://doi.org/10.2166/wh.2019.282>.

Mellor, J.E., Smith, J.A., Samie, A. and Dillingham, R.A. (2013) 'Coliform sources and mechanisms for regrowth in household drinking water in Limpopo, South Africa', Journal of Environmental Engineering 139(9): 1152-61 <http://doi.org/10.1061/(ASCE)EE.1943-7870.0000722>.

MSR (2017) 'MSR, Stanford and Path test chlorine dosing prototype in Kenya', Mountain Safety Research [online] <https://www.msrgear.com/blog/msr-stanford-path-chlorine-dosingkenya/> [accessed 3 March 2020].

Opryszko, M.C., Guo, Y., MacDonald, L., MacDonald, L., Kiihl, S. and Schwab, K.J. (2013) 'Impact of water-vending kiosks and hygiene education on household drinking water quality in rural Ghana', The American Journal of Tropical Medicine and Hygiene 88(4): 651-60 <http:// doi.org/10.4269/ajtmh.12-0065>.

Orner, K.D., Calvo, A., Zhang, J. and Mihelcic, J.R. (2017) 'Effectiveness of in-line chlorination in a developing world gravity-flow water supply', Waterlines $36(2): 167-82<$ https://doi. org/10.3362/1756-3488.16-00016>.

Peter-Varbanets, M., Dreyer, K., McFadden, N., Ouma, H., Wanyama, K., Etenu, C. and Meierhofer, R. (2017) 'Evaluating novel gravity-driven membrane (GDM) water kiosks in schools', paper presented at the 40th WEDC International Conference, Loughborough, UK [online] $<$ https://hdl.handle.net/2134/31530> [accessed 12 March 2021].

Pickering, A.J., Crider, Y., Sultana, S., Swarthout, J., Goddard, F.G., Islam, S.A., Sen, S., Ayyagari, R. and Luby, S.P. (2019) 'Effect of in-line drinking water chlorination at the point of collection on child diarrhoea in urban Bangladesh: a double-blind, cluster-randomised controlled trial', The Lancet Global Health 7(9): e1247-56 <https://doi.org/10.1016/S2214109X(19)30315-8>.

Reed, B., Scott, R., Skinner, B. and Jackson, T. (2011) G004: Domestic Water Containers: An Engineer's Guide, Loughborough, UK: WEDC, Loughborough University.

Roberts, L., Chartier, Y., Chartier, O., Malenga, G., Toole, M. and Rodka, H. (2001) 'Keeping clean water clean in a Malawi refugee camp: a randomized intervention trial', Bulletin of the World Health Organization 79: 280-7.

Skinner, B. (2001) Chlorinating Small Water Supplies, Loughborough, UK: Water, Engineering and Development Centre, Loughborough University.

Steele, A., Clarke, B. and Watkins, O. (2008) 'Impact of jerry can disinfection in a camp environment: experiences in an IDP camp in northern Uganda', Journal of Water and Health 6(4): 559-64 <http://doi.org/10.2166/wh.2008.072>.

Safe Water and AIDS Project (SWAP) (2017) Annual Report 2017, SWAP, Kisumu, Kenya.

Wilhelm, N., Kaufmann, A., Blanton, E. and Lantagne, D. (2018) 'Sodium hypochlorite dosage for household and emergency water treatment: updated recommendations', Journal of Water and Health 16(1): 112-25 <https://doi.org/10.2166/wh.2017.012>.

World Health Organization (WHO) (2017) Guidelines for Drinking-Water Quality: Fourth Edition Incorporating the First Addendum, Geneva, Switzerland: WHO. 
Wright, J., Gundry, S. and Conroy, R. (2004) 'Household drinking water in developing countries: a systematic review of microbiological contamination between source and point-of-use', Tropical Medicine \& International Health 9(1): 106-17 <http://doi.org/10.1046/j.1365-3156.2003.01160.x>.

Yates, T.M., Armitage, E., Lehmann, L.V., Branz, A.J. and Lantagne, D.S. (2015) 'Effectiveness of chlorine dispensers in emergencies: case study results from Haiti, Sierra Leone, Democratic Republic of Congo, and Senegal', Environmental Science \& Technology 49(8): 5115-22 <https:// doi.org/10.1021/acs.est.5b00309>.

Yee, L.F., Abdullah, M.P., Ata, S. and Ishak, B. (2006) 'Dissolved organic matter and its impact on the chlorine demand of treated water', Malaysian Journal of Analytical Sciences 10(2): $243-50$. 